\section{Early-ripening Grapevine Cultivars for Dry-on-vine Raisins on an Open-gable Trellis}

\author{
Matthew W. Fidelibus ${ }^{1,3}$, L. Peter Christensen ${ }^{1}$, \\ Donald G. Katayama ${ }^{1}$, and David W. Ramming ${ }^{2}$
}

AdDitional Index wORDs. DOV, dried vine fruit, grapes, Vitis vinifera

Summary. 'Diamond Muscat', 'DOVine', 'Fiesta', and 'Selma Pete' grapevines ( Vitis vinifera) were evaluated to determine their suitability for making dry-on-vine (DOV) raisins on an open-gable trellis. The experiment was a split-plot, with training system, head, bilateral, or quadrilateral cordons as the main plot, and grapevine cultivar (Diamond Muscat, DOVine, Fiesta, or Selma Pete) as the subplot. Yield components, fruit composition, and raisin yield and quality were evaluated annually. Vine training style did not affect fruit composition, or raisin yield or quality, but vines trained to quadrilateral cordons produced more clusters on renewal shoots than head-trained vines. 'DOVine', 'Fiesta', and 'Selma Pete' produced about 4.75 tons/acre of raisins, $\approx 10 \%$ more than 'Diamond Muscat'. 'Diamond Muscat' vines produced the most clusters on renewal shoots, an undesirable trait, and the most clusters per vine. 'Fiesta' matured later than the other cultivars, therefore it had the lowest soluble solids, the poorest raisin grades, and the highest field moisture at harvest. 'Selma Pete' grapes matured as early, or earlier, than the grapes of other cultivars, they had among the highest soluble solids and raisin grades, and the raisins generally dried well. Thus, 'Selma Pete' grapevines had the best overall performance of the cultivars tested.

$\mathrm{C}$ alifornia produces $30 \%$ to $40 \%$ of the world's raisins (Christensen, 2000a). Most growers still rely on hand labor to pick the grapes and place them on paper trays, between the vine rows, to dry. However, in recent years, farm labor has become less available and more costly, therefore complete mechanization of the raisin-making process is now an important industry goal (Christensen, 2000b). One promising mechanized production concept is dryon-vine (DOV). The DOV method consists of severing grapevine canes bearing clusters of mature fruit, thus separating the clusters from the permanent vine structures and causing the fruit to DOV (May and Kerridge,

This research was made possible by awards from the California Raisin Marketing Board, the Viticulture Consortium West, and the California Competitive Grant Program for Research in Viticulture and Enology.

We thank Jorge Osorio-Aguilar and Kimberley A. Cathline for their valuable assistance in collecting and summarizing the data, and Gwen Conville, for preparing the illustrations. We also thank Amand Kasimatis and Stephen J. Vasquez for their helpful comments on an earlier draft of this manuscript.

${ }^{1}$ Department of Viticulture and Enology, University of California, Davis, and Kearney Agricultural Center, Parlier, CA 93648

${ }^{2}$ U.S. Department of Agriculture-Agricultural Research Service, Crop Diseases, Pests, and Genetics Research Unit, Parlier, CA 93648

${ }^{3}$ Corresponding author. E-mail: mwf@uckac.edu.
1967). When dry, the raisins are removed from the trellised vines with a mechanical harvester.

Californians initially resisted adopting the DOV method, partly because there was insufficient economic incentive when labor was relatively plentiful and inexpensive. Also, California's dominant raisin grape cultivar, Thompson Seedless, matures cool temperatures hinder DOV (Fidelibus et al., 2007; Peacock and Swanson, 2005; Studer and Olmo, 1973). Application of an ethyl oleate and potassium carbonate emulsion to the grapes facilitates DOV (Clingeleffer, 2006; Grncarevic and Lewis, 1976; May and Kerridge, 1967), but such treatments are discouraged in California because a domestic market for the treated raisins, which have a different color, texture, and flavor than the traditional "naturals" has not late in the season when short days and been developed (Angulo et al., 2007; Enochian et al., 1976).

Natural DOV raisins may be produced from grapes that ripen earlier than 'Thompson Seedless' because the earlier ripening will allow the drying process to start when days are longer and temperatures are higher (Aung et al., 2002). Thus, 'Fiesta', a white seedless raisin grape that ripens about 1 week before 'Thompson Seedless' (Weinberger and Loomis, 1974), may be used as a DOV cultivar. The first grape cultivar selected for natural DOV raisin production, 'DOVine', was released in 1995. Two additional cultivars intended for DOV raisin production, 'Diamond Muscat' and 'Selma Pete', were released in 2000 and 2001, respectively (Okie, 2002). Growers considering the development of a new DOV vineyard may find it difficult to make an informed decision on which cultivar to plant because data from replicated trials evaluating the performance of these varieties have not been published.

To maximize the potential of a new DOV raisin vineyard, growers must choose an appropriate trellis. Trellis dimensions in traditional raisin vineyards are constrained by the need for sunlit row middles during tray drying, but larger trellises may be used in DOV vineyards because the fruit will dry on trellises rather than in the row middles (Clingeleffer, 2006; Shrestha and Fidelibus, 2005). Therefore, the large open-gable or "Y" trellises, which have typically been used for table grapes (Mollah, 2001; Winkler et al., 1974), may also be used in DOV raisin vineyards. The open-gable trellis should enable greater yields than a traditional trellis because yields generally increase with trellis dimensions (Kasimatis et al., 1975; Winkler et al., 1974), but raisin yields from an open-gable trellis have not been reported. Vines in traditional raisin vineyards are usually head-trained, but it may be desirable

\begin{tabular}{llll}
\hline $\begin{array}{l}\text { Units } \\
\text { To convert U.S. to SI, } \\
\text { multiply by }\end{array}$ & U.S unit & SI unit & $\begin{array}{l}\text { To convert SI to U.S., } \\
\text { multiply by }\end{array}$ \\
\hline 10 & $\%$ & $\mathrm{~g} \cdot \mathrm{L}^{-1}$ & 0.1 \\
0.4047 & $\mathrm{acre}(\mathrm{s})$ & $\mathrm{ha}$ & 2.4711 \\
0.3048 & $\mathrm{ft}$ & $\mathrm{m}$ & 3.2808 \\
2.54 & inch(es) & $\mathrm{cm}$ & 0.3937 \\
0.4536 & $\mathrm{lb}$ & $\mathrm{kg}$ & 2.2046 \\
28.3495 & $\mathrm{oz}$ & $\mathrm{g}$ & 0.0353 \\
2.2417 & ton/acre & $\mathrm{Mg} \cdot \mathrm{ha}^{-1}$ & 0.4461
\end{tabular}


to train vines on open-gable trellises to bilateral or quadrilateral cordons because those training systems facilitate cane severance and winter pruning. Some cultivars are not well suited to cordon training, therefore the potential effects of training systems on yield and quality should be evaluated. Thus, the primary purpose of this study was to evaluate the performance of 'Diamond Muscat', 'DOVine', 'Fiesta', and 'Selma Pete' grapevines for DOV raisin production on an open-gable trellis, and a secondary objective was to determine whether the different training systems affected vine performance.

\section{Materials and methods}

The experiment was conducted at the Kearney Agricultural Center, Parlier, CA (lat. 36 $36^{\prime} 42^{\prime \prime} \mathrm{N}$, long. $119^{\circ} 31^{\prime} 34^{\prime \prime} \mathrm{W}$, altitude $\left.338 \mathrm{ft}\right)$. Own-rooted cuttings of 'Diamond Muscat', 'DOVine', 'Fiesta', and 'Selma Pete' grapevines were planted in 1994 in a Hanford sandy loam having a restrictive feature more than 80 inches below the soil surface (U.S. Department of Agriculture, 2008). Vines were planted in east-west rows, at a spacing of $7.5 \mathrm{ft}$ within rows and $12 \mathrm{ft}$ between rows. All vines were irrigated and subjected to other cultural practices considered normal and ordinary for raisin grapes in the San Joaquin Valley. The experiment used a split-plot design with training method (head, bilateral, or quadrilateral cordon) the main-plot factor, replicated three times, and cultivar (Diamond Muscat, DOVine, Fiesta, and Selma Pete), the subplot factor, replicated nine times. Each subplot consisted of three consecutive vines in a row; data were collected from the center vine of each subplot, and the other two vines served as guards.

All vines were supported by an open-gable trellis (Fig. 1). The trellis consisted of steel posts spaced $22.5 \mathrm{ft}$ apart. The posts were topped at $4.5 \mathrm{ft}$ by steel V-shaped cross-arm assemblies. The cross-arm assembly was $6 \mathrm{ft}$ wide and supported six fruiting wires, three on each side. The basal wires were placed about 21 inches from the base of the cross-arm assembly, and the two other wires on each arm were evenly spaced at 8 -inch intervals. The angle formed by the cross-arms on the post was about $140^{\circ}$. A vertical 1 $\mathrm{ft}$-tall post extension was mounted in

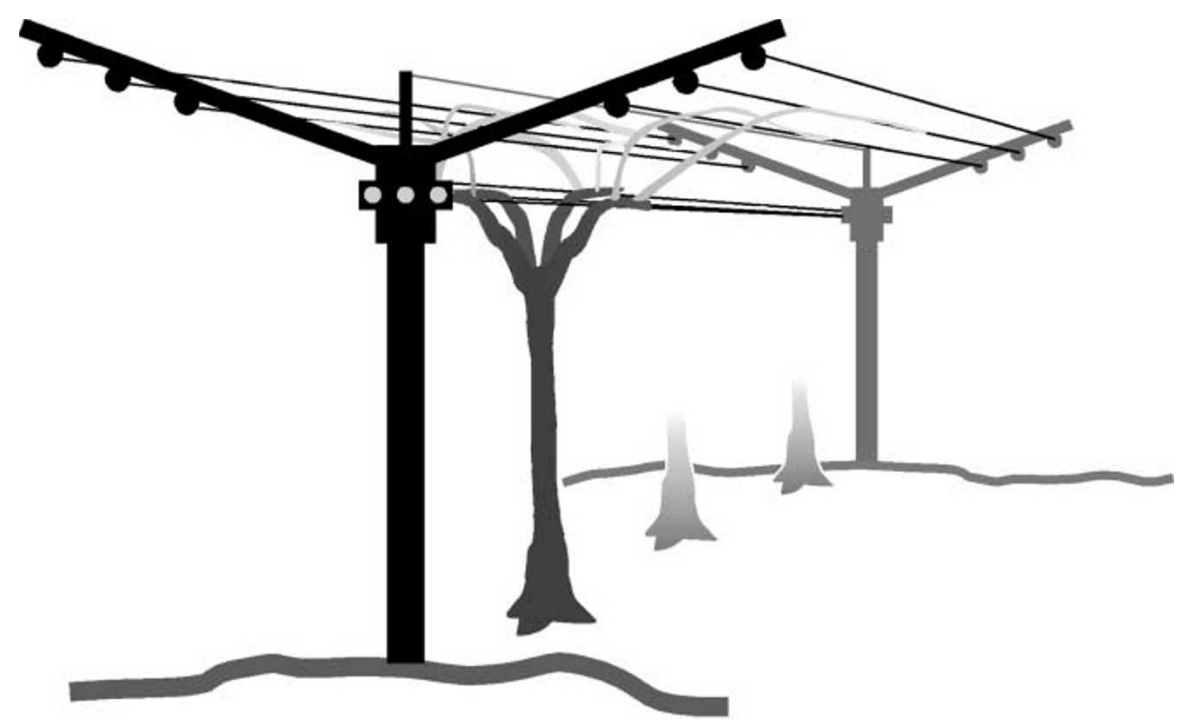

Fig. 1. Open-gable trellis system for grapes. the center of each cross-arm assembly to support a single foliar catch wire. Vines with bilateral cordons were further supported by a wire mounted at the base of the cross arm assembly, and vines with quadrilateral cordons had a parallel set of cordon wires, each of which were mounted $4.5 \mathrm{ft}$ above the soil surface with a horizontal separation of $1 \mathrm{ft}$ (Figs. 1 and 2 ).

The permanent vine structures (trunk, and arms or cordons; Fig. 2) were established by 1997, and the vines were first subjected to annual cane severance for DOV that year. Thereafter, the vines were cane pruned each winter. During the study period, 2000 through 2003, each vine was pruned to seven or eight canes per vine, with $\approx 15$ nodes per cane. Canes were tied to one of the three fruiting wires on each side of the cross-arm assembly (Fig. 2). Shoots arising from spurs, renewal shoots, were trained to the foliage catch wire in the center of the trellis, thereby separating the fruiting and renewal portions of the vine's foliage. Thus, the open-gable DOV trellis system has a balanced distribution of fruit and a horizontally divided canopy.

Inflorescences on each vine were counted each spring from 2001 through 2003. Clusters on shoots arising from spurs were removed as they were counted because it is undesirable to allow clusters of fruit to develop on renewal shoots. The drying of such clusters would not be initiated by cane severance and thus would require individual hand harvest (Peacock and Swanson, 2005). The proportion of clusters on canes was calculated.

Each July, composite berry samples were collected weekly to monitor the grapes' accumulation of soluble solids. Samples consisted of $\approx 100$ berries collected from the top, middle, and bottom of $\approx 33$ randomly selected clusters. The samples were weighed, and average berry weight was calculated. The berries were then homogenized in a blender, the juice was filtered, and soluble solids were measured with a hand-held,

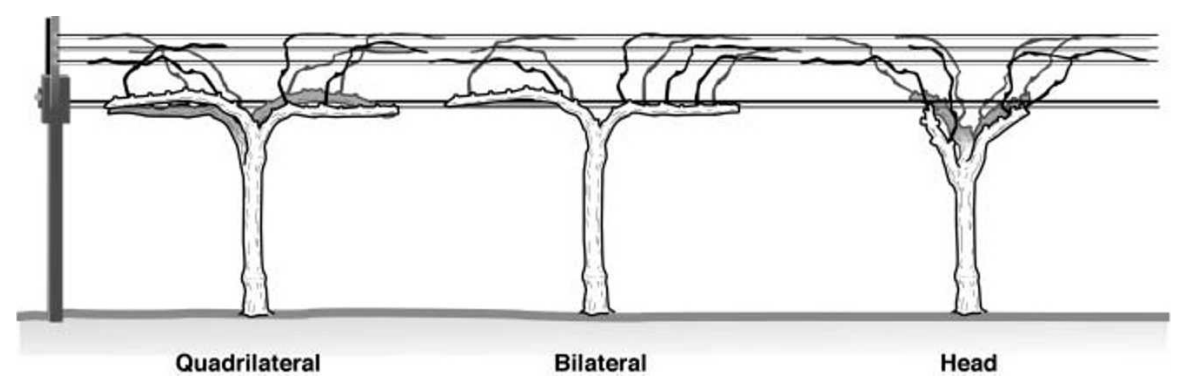

Fig. 2. The permanent structures and fruiting canes of grapevines trained to quadrilateral cordons, bilateral cordons, and head training systems. 
temperature-compensating, digital refractometer (Palette 101; Atago, Farmingdale, NY). Titratable acidity of the juice was determined by titration with $0.133 \mathrm{~N} \mathrm{NaOH}$ to an 8.20 endpoint using an automatic titrator (900A; Orion Research, Boston). After berries amassed sufficient soluble solids for raisin making, $>20 \%$ soluble solids (Baranek et al., 1970), the canes were severed above the third or fourth basal node with pruning shears. Any clusters of fruits on shoots from the basal buds were clipped off the vine and hung on the trellis wires. Cane severance dates for each cultivar and year are shown in Table 1. Canes of different cultivars were sometimes severed on different days within a year in an attempt to match soluble solids; however, if cane severance is delayed much beyond mid-August, grapes usually will not dry sufficiently (Fidelibus et al., 2007; Peacock and Swanson, 2005), therefore canes of all cultivars were severed by 19 Aug., regardless of soluble solids.

Fruits of each vine were inspected weekly as they dried. Raisins were harvested when moisture levels had decreased to about 14\%, or when weather forecasts indicated that the berries were unlikely to continue to dry. Therefore, raisin harvest dates differed between cultivars in some years; raisin harvest dates for each cultivar and year are shown in Table 1. At harvest, the raisins of each data vine were collected, weighed, mixed, and 2 -kg subsamples were removed and sealed in polyethylene bags. After all subsamples were prepared, they were shipped to the USDA Processed Products Division, Fresno, CA, where trained inspectors determined airstream sorter grades and percentage of moisture of the raisins (Kagawa, 2000). The mass of raisins from each plot was standardized to $14 \%$ moisture for statistical comparisons of yield (Fidelibus et al., 2007). Yield was then expressed on the basis of tons per acre by multiplying the standardized raisin weight per plot by the number of vines per acre (484). Data were subjected to analysis of variance (PROC GLM; SAS Institute, Cary, NC). The effects of year, and any potential interactions between year and training system and cultivar, were considered random effects. When significant interaction effects between two factors were observed, the means of one factor were compared at each level of the other factor by Duncan's new multiple range test, or by least significant difference, as appropriate (Gomez and Gomez, 1984). In the absence of interactions, significant differences between the levels of individual factors were determined by Duncan's new multiple range test.

\section{Results and discussion}

The number of inflorescences per vine, and the proportion of inflorescences borne on canes, differed between some years as expected, but the effects of the training system and cultivar on these yield components were consistent and independent of year (Table 2). Vines trained to quadrilateral cordons produced more inflorescences than head-trained vines, but a smaller proportion of their inflorescences were on canes compared with vines trained to heads or bilateral cordons (Table 2). Quadrilateral cordons essentially increase a vines' trunk length compared with bilateral cordons or heads, which increases the potential number of spurs per vine (Winkler et al., 1974). Thus, vines trained to quadrilateral cordons probably had more basal shoots than vines subjected to the other training systems. Some basal shoots will bear inflorescences, thereby increasing the number of inflorescences per vine, and decreasing the proportion of inflorescences borne on canes. Inflorescences were removed from basal shoots in spring, thus training system ultimately did not affect the number of clusters per vine (Table 2 ).

'Diamond Muscat' produced $40 \%$ to $45 \%$ more inflorescences per vine than the other cultivars, and it had the lowest proportion of inflorescences on canes (Table 2). Together, these data suggest that 'Diamond Muscat' grapevines have higher basal bud fertility than the other cultivars. 'Fiesta' had the fewest inflorescences per vine and the highest proportion on canes, in agreement with the original description of 'Fiesta' as having low basal bud fertility (Weinberger and Loomis, 1974). Clusters of fruit on basal shoots are undesirable for DOV raisin production because canes are generally severed at the third or fourth node, thus grapes on shoots from the first three nodes will not DOV and must be hand harvested (Peacock and Swanson, $2005)$. The hand harvest of fruit is laborious and at odds with the goal of developing a completely mechanized harvest system. Depending on the value of the raisins, the most economical method of dealing with clusters on basal shoots may be to remove the inflorescences in the spring (Vasquez et al., 2003), therefore the ideal DOV cultivar would have low basal bud fruitfulness and thus require minimal inflorescence removal.

Even after removing the inflorescences from basal shoots, 'Diamond Muscat' grapevines still had the most clusters per vine, followed by 'Fiesta' and 'Selma Pete,' and then 'DOVine', which produced $40 \%$ fewer clusters per vine than 'Diamond Muscat' (Table 2). Despite the considerable variation in cluster counts, most cultivars had berries of similar fresh weight, except 'Selma Pete', which produced berries that were about $10 \%$ heavier than the others (Table 2 ). The berry fresh weights of 'Fiesta' and 'Selma Pete' were similar to those reported earlier (Angulo et al., 2007).

Table 1. Dates when canes were severed, and raisins harvested, from grapevines in Parlier, CA.

\begin{tabular}{|c|c|c|c|c|c|c|c|c|}
\hline \multirow[b]{3}{*}{ Cultivar } & \multicolumn{8}{|c|}{ Year } \\
\hline & \multicolumn{2}{|c|}{2000} & \multicolumn{2}{|c|}{2001} & \multicolumn{2}{|c|}{2002} & \multicolumn{2}{|c|}{2003} \\
\hline & Cane-cut & Harvest & Cane-cut & Harvest & Cane-cut & $\overline{\text { Harvest }}$ & Cane-cut & Harvest \\
\hline DOVine & 15 Aug. & 10 Oct. & 2 Aug. & 10 Sept. & 12 Aug. & 10 Oct. & 7 Aug. & 8 Oct. \\
\hline Fiesta & 15 Aug. & 10 Oct. & 8 Aug. & 12 Sept. & 19 Aug. & 10 Oct. & 7 Aug. & 25 Sept. \\
\hline Selma Pete & 15 Aug. & 10 Oct. & 2 Aug. & 6 Sept. & 7 Aug. & 25 Sept. & 7 Aug. & 25 Sept. \\
\hline
\end{tabular}


Table 2. Effect of year, training style, and grapevine cultivar on the number of inflorescences/vine, proportion of clusters born on canes, number of retained clusters/vine, and berry weight at Parlier, CA.

\begin{tabular}{|c|c|c|c|c|}
\hline Factor & $\begin{array}{c}\text { Inflorescences/vine } \\
\text { (no.) }\end{array}$ & $\begin{array}{c}\text { Clusters on } \\
\text { canes (\%) }\end{array}$ & $\begin{array}{l}\text { Fruit clusters/vine } \\
\text { (no.) }\end{array}$ & $\begin{array}{l}\text { Berry } \\
\text { wt (g) }\end{array}$ \\
\hline \multicolumn{5}{|l|}{ Year } \\
\hline 2000 & - & - & - & $1.0 c^{z}$ \\
\hline 2001 & $155 \mathrm{a}$ & $74 \mathrm{c}$ & $113 \mathrm{~b}$ & $2.1 \mathrm{~b}$ \\
\hline 2002 & $159 \mathrm{a}$ & $83 a$ & $130 \mathrm{a}$ & $2.0 \mathrm{~b}$ \\
\hline 2003 & $104 \mathrm{~b}$ & $78 \mathrm{~b}$ & $79 \mathrm{c}$ & $2.9 \mathrm{a}$ \\
\hline \multicolumn{5}{|l|}{ Training style } \\
\hline Head & $133 \mathrm{~b}$ & $81 \mathrm{a}$ & 106 & 2.02 \\
\hline Bilateral & $138 \mathrm{ab}$ & $81 \mathrm{a}$ & 110 & 1.97 \\
\hline Quadrilateral & $146 \mathrm{a}$ & $73 \mathrm{~b}$ & 106 & 2.00 \\
\hline \multicolumn{5}{|l|}{ Cultivar } \\
\hline Diamond Muscat & $208 \mathrm{a}$ & $72 \mathrm{~d}$ & $148 \mathrm{a}$ & $1.97 \mathrm{~b}$ \\
\hline DOVine & $116 \mathrm{bc}$ & $76 \mathrm{c}$ & $89 \mathrm{c}$ & $1.96 \mathrm{~b}$ \\
\hline Fiesta & $113 \mathrm{c}$ & $85 \mathrm{a}$ & $96 \mathrm{bc}$ & $1.88 \mathrm{~b}$ \\
\hline Selma Pete & $127 \mathrm{~b}$ & $80 \mathrm{~b}$ & $101 \mathrm{~b}$ & $2.20 \mathrm{a}$ \\
\hline \multicolumn{5}{|l|}{ Significance } \\
\hline Year $(Y)$ & $<0.01$ & $<0.01$ & $<0.01$ & $<0.01$ \\
\hline Training style (TS) & 0.02 & $<0.01$ & 0.37 & 0.78 \\
\hline Cultivar (C) & $<0.01$ & $<0.01$ & $<0.01$ & $<0.01$ \\
\hline $\mathrm{TS} \times \mathrm{C}$ & 0.35 & 0.17 & 0.48 & 0.96 \\
\hline $\mathrm{Y} \times \mathrm{TS} \times \mathrm{C}$ & 0.62 & 0.71 & 0.52 & 0.99 \\
\hline
\end{tabular}

${ }^{2}$ Values are treatment means, $\mathrm{n}=36,48$, or 36 , for year, training system, and cultivar, respectively. Means followed by different letters, within columns and factors, are significantly different at the $5 \%$ level according to Duncan's new multiple range test; $1 \mathrm{~g}=0.0353 \mathrm{oz}$.

'Diamond Muscat', 'DOVine', and 'Selma Pete' grapes amassed similar quantities of soluble solids, but 'Fiesta' had about $10 \%$ less soluble solids than the other cultivars (Table 3), even though the severance of 'Fiesta' canes was sometimes delayed (Table 1) in an attempt to achieve similar levels of soluble solids among all cultivars. Thus, when subjected to DOV management practices, 'Fiesta' was clearly the latest maturing cultivar-an undesirable trait. The cultivars varied considerably with respect to titratable acidity; 'Selma Pete' had the highest acidity, followed by 'Fiesta', 'DOVine', and 'Diamond Muscat' ('Table 3). These data agree with an earlier observation that 'Selma Pete' berries were more acidic than 'Fiesta', even though 'Selma Pete' had higher soluble solids (Angulo et al., 2007). Titratable acidity of fresh grapes is not a good predictor of raisin grades (Christensen et al., 1995), but raisins made from acidic grapes may have a sour flavor that appeals to some groups of consumers but not to others (Angulo et al., 2007).

Annual raisin yields across training systems and cultivars ranged from 3.3 to 5.9 tons/acre of raisins (Table 4). Comparable yields were achieved from 'Sunmuscat' grapevines on the hanging cane system, a modern trellis drying system designed for the production of light-colored dried fruit (Clingeleffer, 2006), and both systems produced 1.5 to 3 times the average yield of a typical conventional raisin vineyard (Christensen, 2000a). Each individual cultivar produced relatively good yields, although 'DOVine', 'Fiesta', and 'Selma Pete' had yields that were about $12 \%$ greater than those of 'Diamond Muscat' (Table 4). The yield data, together with cluster counts and berry weights, suggest that 'Diamond Muscat' clusters must have been smaller, with fewer berries, than the other cultivars, whereas the clusters of 'DOVine' and 'Fiesta' must have been larger, with more berries, than the others.

More than $80 \%$ of the 'Diamond Muscat', 'DOVine', and 'Selma Pete' raisins were judged "B and better," California's highest grade (Christensen, 2000c), whereas only about 70\% of the 'Fiesta' raisins received a " $\mathrm{B}$ and better" grade (Table 4). Relatively few raisins received a substandard grade, regardless of the training system or grapevine cultivar (Table 4 ). Raisin grades are highly correlated with soluble solids (Baranek et al., 1970; Christensen et al., 1995; Jacob,
1942), therefore the lower grades of 'Fiesta' are likely due, in part, to their lower soluble solids. In California, growers are currently paid bonuses that increase with the proportion of their raisins receiving a "B and better" grade, up to $75 \%$ "B and better." Thus, the raisin crop from all cultivars except 'Fiesta' would receive the maximum payments based on quality. When yield and quality are considered together, 'DOVine' and 'Selma Pete' were superior to the other cultivars as they produced the most " $\mathrm{B}$ and better" raisins per acre (Table 4 ).

'Diamond Muscat' and 'Selma Pete' dried to lower moisture contents than 'DOVine' or 'Fiesta' (Table 4). Raisin drying depends on the duration and temperature of the drying period. Thus, the relatively early maturity and cane severance of 'Diamond Muscat' and 'Selma Pete' facilitated the drying of their fruits, whereas the relatively late maturity of 'Fiesta' inhibited drying. It is uncertain why 'DOVine' grapes did not dry as well as 'Selma Pete' and 'Diamond Muscat' grapes; perhaps their relatively large clusters may have inhibited berry drying. Raisins from each grapevine cultivar were, on average, able to dry below $16 \%$, the maximum moisture content accepted by California raisin packers (Kagawa, 2000). However, sugaring, a postharvest disorder of raisins, can be a major problem for raisins having a moisture content $>15 \%$ (Christensen and Peacock, 2000), thus the drying performance of 'DOVine' and 'Fiesta' was marginal.

In conclusion, 'Selma Pete' grapes matured as early, or earlier, than the others, their berry mass was greater, and their yield and quality were similar, or better, than the other cultivars tested. 'DOVine' shared many of the desirable traits of 'Selma Pete', but its berries did not dry as well. 'Diamond Muscat' grapes bore an excessive number of clusters on renewal shoots, but the remaining grapes ripened early, dried well, and produced good quality raisins. 'Fiesta' grapes produced few clusters on renewal shoots, a desirable characteristic, but the grapes ripened slowly, which required the canes to be severed before enough soluble solids were amassed to assure optimum raisin quality. Moreover, the late cane severance inhibited berry drying. Thus, 'Selma Pete' appears to be the best choice for making DOV raisins on an open-gable trellis. 
Table 3. Effect of year, training style, and grapevine cultivar on berry composition at Parlier, CA.

\begin{tabular}{lcc}
\hline & \multicolumn{2}{c}{ Berry composition } \\
\cline { 2 - 3 } Factor & $\begin{array}{c}\text { Soluble solids } \\
\text { concentration (\%) }\end{array}$ & $\begin{array}{c}\text { Titratable acidity } \\
\left(\mathbf{g} \cdot \mathbf{L}^{-1}\right)^{\mathbf{z}}\end{array}$ \\
\hline Year & $20.1 \mathrm{c}^{\mathrm{y}}$ & $0.43 \mathrm{ab}$ \\
2000 & $21.5 \mathrm{ab}$ & $0.44 \mathrm{a}$ \\
2001 & $22.1 \mathrm{a}$ & $0.41 \mathrm{~b}$ \\
2002 & $21.3 \mathrm{~b}$ & $0.43 \mathrm{a}$ \\
2003 & & \\
Training style & 21.1 & 4.24 \\
Head & 21.3 & 4.29 \\
Bilateral & 21.2 & 4.29 \\
Quadrilateral & & \\
Cultivar & $21.9 \mathrm{a}$ & $0.38 \mathrm{c}$ \\
Diamond Muscat & $21.9 \mathrm{a}$ & $0.36 \mathrm{~d}$ \\
DOVine & $19.4 \mathrm{~b}$ & $0.42 \mathrm{~b}$ \\
Fiesta & $21.8 \mathrm{a}$ & $0.55 \mathrm{a}$ \\
Selma Pete & & $<0.01$ \\
Significance & $<0.01$ & 0.66 \\
Year (Y) & 0.92 & $<0.01$ \\
Training style (TS) & $<0.01$ & 0.12 \\
Cultivar (C) & 0.93 & 0.73 \\
TS $\times$ C & 0.99 & \\
Y $\times$ TS $\times$ C & &
\end{tabular}

${ }^{2} 1 \mathrm{~g} \cdot \mathrm{L}^{-1}=0.1 \%$.

'Values are treatment means, $\mathrm{n}=36,48$, or 36 , for year, training system, and cultivar, respectively. Means followed by different letters, within columns and factors, are significantly different at the $5 \%$ level according to Duncan's new multiple range test.

Table 4. Effect of year, training style, and grapevine cultivar on raisin yield and quality at Parlier, CA.

\begin{tabular}{|c|c|c|c|c|c|}
\hline \multirow[b]{2}{*}{ Factor } & \multirow[b]{2}{*}{$\begin{array}{c}\text { Yield } \\
(\text { tons } / \text { acre })^{\mathrm{z}}\end{array}$} & \multicolumn{2}{|r|}{ Grade } & \multirow[b]{2}{*}{$\begin{array}{c}\text { B\&B yield } \\
\text { (tons/acre) }\end{array}$} & \multirow[b]{2}{*}{$\begin{array}{c}\text { Moisture } \\
(\%)\end{array}$} \\
\hline & & $\begin{array}{c}\mathbf{B}^{2} \mathrm{~B}^{\mathrm{y}} \\
(\%)\end{array}$ & $\begin{array}{c}\text { Substandard } \\
(\%)\end{array}$ & & \\
\hline \multicolumn{6}{|l|}{ Year } \\
\hline 2000 & $4.6 b^{x}$ & $68.8 \mathrm{c}$ & $6.2 \mathrm{a}$ & $3.1 \mathrm{c}$ & $12.7 \mathrm{c}$ \\
\hline 2001 & $4.6 \mathrm{~b}$ & $89.4 \mathrm{a}$ & $1.8 \mathrm{~b}$ & $4.1 \mathrm{~b}$ & $14.9 \mathrm{a}$ \\
\hline 2002 & $5.9 \mathrm{a}$ & $86.3 \mathrm{a}$ & $3.1 \mathrm{~b}$ & $5.1 \mathrm{a}$ & $14.1 \mathrm{~b}$ \\
\hline 2003 & $3.3 \mathrm{c}$ & $77.8 \mathrm{~b}$ & $3.0 \mathrm{~b}$ & $2.6 \mathrm{~d}$ & $14.8 \mathrm{a}$ \\
\hline \multicolumn{6}{|l|}{ Training style } \\
\hline Head & 4.56 & 82.0 & 3.3 & 3.7 & 14.2 \\
\hline Bilateral & 4.54 & 79.6 & 3.8 & 3.6 & 14.1 \\
\hline Quadrilateral & 4.68 & 80.1 & 3.6 & 3.8 & 14.3 \\
\hline \multicolumn{6}{|l|}{ Cultivar } \\
\hline Diamond Muscat & $3.99 \mathrm{~b}$ & $85.4 \mathrm{a}$ & 3.3 & $3.4 \mathrm{~b}$ & $13.4 \mathrm{c}$ \\
\hline DOVine & $4.89 \mathrm{a}$ & $82.0 \mathrm{a}$ & 3.0 & $4.0 \mathrm{a}$ & $14.5 \mathrm{~b}$ \\
\hline Fiesta & $4.90 \mathrm{a}$ & $69.1 \mathrm{~b}$ & 4.3 & $3.5 \mathrm{~b}$ & $15.3 \mathrm{a}$ \\
\hline Selma Pete & $4.52 \mathrm{a}$ & $86.3 \mathrm{a}$ & 3.6 & $3.9 \mathrm{a}$ & $13.3 \mathrm{c}$ \\
\hline \multicolumn{6}{|l|}{ Significance } \\
\hline Year (Y) & $<0.01$ & $<0.01$ & $<0.01$ & $<0.01$ & $<0.01$ \\
\hline Training style (TS) & 0.68 & 0.48 & 0.62 & 0.68 & 0.64 \\
\hline Cultivar (C) & $<0.01$ & $<0.01$ & 0.09 & $<0.01$ & $<0.01$ \\
\hline $\mathrm{TS} \times \mathrm{C}$ & 0.99 & 0.88 & 0.95 & 0.95 & 0.22 \\
\hline $\mathrm{Y} \times \mathrm{TS} \times \mathrm{C}$ & 0.99 & 0.90 & 0.99 & 0.90 & 0.50 \\
\hline
\end{tabular}

${ }^{\mathrm{z}} 1$ ton $/$ acre $=2.2417 \mathrm{Mg} \cdot \mathrm{ha}^{-1}$.

" $\mathrm{B} \& \mathrm{~B}=$ "B and better," California's highest raisin grade.

"Values are treatment means, $\mathrm{n}=36,48$, or 36, for year, training system, and cultivar, respectively. Means followed by different letters, within columns and factors, are significantly different at the $5 \%$ level according to Duncan's new multiple range test.

\section{Literature cited}

Angulo, O., M.W. Fidelibus, and H. Heymann. 2007. Grape cultivar and drying method affect sensory characteristics and consumer preference of raisins. J. Sci. Food Agr. 87:865-870.

Aung, L.H., D.W. Ramming, and R. Tarailo. 2002. Changes in moisture, dry matter and soluble sugars of dry-on-thevine raisins with special reference to sorbitol. J. Hort. Sci. Biotechnol. 77: 100-105.

Baranek, P., M.W. Miller, A.N. Kasimatis, and C.D. Lynn. 1970. Influence of soluble solids in 'Thompson Seedless' grapes on airstream grading for raisin quality. Amer. J. Enol. Viticult. 21:19-25.

Christensen, L.P. 2000a. Background and resources, p. 3-8. In: L.P. Christensen (ed.). Raisin production manual. Univ. California, Agr. Natural Resources, Oakland.

Christensen, L.P. 2000b. Current developments in harvest mechanization and DOV, p. 252-263. In: L.P. Christensen (ed.). Raisin production manual. Univ. California, Agr. Natural Resources, Oakland.

Christensen, L.P. 2000c. Raisin quality, p. 228-235. In: L.P. Christensen (ed.). Raisin production manual. Univ. California, Agr. Natural Resources, Oakland.

Christensen, L.P. and W.L. Peacock. 2000. The raisin drying process, p. 207216. In: L.P. Christensen (ed.). Raisin production manual. Univ. California, Agr. Natural Resources, Oakland.

Christensen, L.P., M.L. Bianchi, M.W. Miller, A.N. Kasimatis, and C.D. Lynn. 1995. The effects of harvest date on Thompson Seedless grapes and raisins. II. Relationships of fruit quality factors. Amer. J. Enol. Viticult. 46:493-498.

Clingeleffer, P.R. 2006. Management practices for Sunmuscat (Vitis vinifera L.): A new drying variety. Aust. J. Grape Wine Res. 12:128-134.

Enochian, R.V., M.D. Zehner, S.S. Johnson, and V.E. Petrucci. 1976. Production costs and consumer acceptance of driedon-the-vine raisins. U.S. Dept. Agr., Natl. Econ. Analysis Div., Agr. Econ. Rpt. No. 337.

Fidelibus, M.W., S.J. Vasquez, and K.A. Cathline. 2007. Canopy separation and defoliation do not improve the dry-onvine raisin-making method for 'Thompson Seedless' grapevines on traditional trellises. J. Amer. Pomol. Soc. 61:61-70.

Gomez, K.A. and A.A. Gomez. 1984. Statistical procedures for agricultural research. Wiley, New York. 
Grncarevic, M. and W.J. Lewis. 1976. Drying of grapes in Australia. Food Technol. Austral. 28:66-67,69-71,76.

Jacob, H.E. 1942. The relation of maturity of the grapes to the yield, composition, and quality of raisins. Hilgardia 14:321345 .

Kagawa, Y. 2000. Quality standards and inspection, p. 236-241. In: L.P. Christensen (ed.). Raisin production manual. Univ. California, Agr. Natural Resources, Oakland.

Kasimatis, A.N., L.A. Lider, and W.M. Kliewer. 1975. Influence of trellising on growth and yield of 'Thompson Seedless' vines. Amer. J. Enol. Viticult. 26:125129.

May, P. and G.H. Kerridge. 1967. Harvest pruning of Sultana vines. Vitis 6:390-393.
Mollah, M. 2001. Practical aspects of grapevine trellising. Winetitles, Adelaide, Australia.

Okie, W.R. 2002. Register of new fruit and nut varieties, List 41 . HortScience 37:251-272.

Peacock, W.L. and F.H. Swanson. 2005 The future of California raisins is drying on the vine. California Agr. 59: 70-74.

Shrestha, A. and M.W. Fidelibus. 2005 Grapevine row orientation affects light environment, growth, and development of black nightshade (Solanum nigrum). Weed Sci. 53:802-812.

Studer, H.E. and H.P. Olmo. 1973. Vine drying of Thompson Seedless grapes. Trans. Amer. Soc. Agr. Eng. 16:944948.
U.S. Department of Agriculture. 2008. USDA Natural Resources Conservation Service web soil survey. 24 Jan. 2008. <http://websoilsurvey.sc.egov. usda.gov/ImsOutput/WssNavigate_ WSSIMS04AV3008605611.png>

Vasquez, S.J., G.M. Leavitt, W.L. Peacock, L.P. Christensen, S.R. Sutter, K.J. Hembree, K.L. Klonsky, D.G. Katayama, and R.L. DeMoura. 2003. Sample costs to establish a vineyard and produce driedon-vine raisins: Early maturing varieties, open gable trellis system, San Joaquin Valley. Univ. California Coop. Ext. Dept. Agr. Resource Econ., Davis.

Weinberger, J.H. and N.H. Loomis. 1974. 'Fiesta' grape. HortScience 9:603.

Winkler, A.J., J.A. Cook, W.M. Kliewer, and L.A. Lider. 1974. General viticulture. 2nd ed. Univ. California Press, Berkeley. 